Jurnal Kejuruteraan 28(2016): 9-18

\title{
The Study of Polymer Material Characterisation Using M-Z-N Statistical Analysis Method
}

\author{
(Kajian Pencirian Bahan Polimer Menggunakan Kaedah Analisis Statistik M-Z-N) \\ Muhamad Arif Fadli Ahmad, Mohd Zaki Nuawi*, Nadia F. Mohamed, \\ Zaliha Wahid \& M. Dirhamsyah
}

\begin{abstract}
This paper proposes an implementation of alternative statistical signal analysis method in characterising material properties of polymer using impulse excitation technique (IET) in accordance with ASTM E1876 standard. Five types of cylindrical shape polymer specimens are used, namely acrylics (AC), poly vinyl chloride (PVC), polyethylene (PE), cast nylon (MC), and polyoxymethylene (POM). Experimental procedure is done based on non-destructive testing (NDT) concept by tapping the specimens using an impact hammer within a specific range of impact force, while accelerometer sensor Endevco 751-100 is used to detect the vibration produced. The detected vibration and the impact force signal which is triggered by impact hammer are captured using NI 9234 data acquisition device and computer. The signal is interpreted and statistically analysed using Mesokurtosis Zonal Non-parametric (M-Z-N) analysis method. As a result, mathematical model equations for determining two material properties which are tensile strength and thermal conductivity have been successfully developed. They are derived through correlation between the signal data and M-Z-N coefficient. Verification of the equation is done and the calculated errors to be in the range of 5.55\% to 9.74\%. Hence, this proves that the correlation can be used as a standard for determining these material properties through M-Z-N method, which is efficient and low cost.
\end{abstract}

Keywords: M-Z-N; impulse excitation technique; non-destructive testing; material characterisation; vibration signal

ABSTRAK

Kertas kerja ini membincangkan pelaksanaan kaedah analisis statistik alternatif dalam mencirikan sifat-sifat bahan polimer dengan menggunakan teknik pengujaan impulsif (IET) berasaskan piawaian ASTM E1876. Lima jenis spesimen polimer berbentuk silinder digunakan iaitu akrilik (AC), poli vinil klorida (PVC), polietilena (PE), nilon tuang (MC), dan polioksimetilena (POM). Prosedur eksperimen dilakukan berdasarkan konsep ujian tanpa musnah dengan mengetuk specimen-spesimen tersebut menggunakan tukul impak mengikut julat daya impak yang tertentu, manakala penderia meter pecut Endevco 751-100 pula digunakan untuk mengesan getaran yang terhasil. Getaran yang dikesan dan juga isyarat daya impak yang dicetuskan oleh tukul impak ditangkap dengan menggunakan pemeroleh data NI 9234 dan komputer. Isyarat itu kemudiannya ditafsir dan dianalisis secara statistik menggunakan kaedah Mesokurtosis Zonal Nonparametric, M-Z-N. Hasilnya, persamaan model matematik bagi memperolehi dua sifat bahan iaitu kekuatan tegangan dan kekonduksian terma telah berjaya dikenalpasti. Ia diperolehi melalui kolerasi antara data isyarat dengan pekali M-Z-N. Pengesahan persamaan tersebut telah dilakukan dan kiraan ralat berada dalam julat 5.55\% hingga 9.74\%. Oleh itu, ini membuktikan bahawa proses kolerasi boleh digunakan sebagai satu piawai dalam menentukan sifat-sifat bahan tersebut melalui kaedah analisis M-Z-N, di mana ianya cekap dan berkos rendah.

Kata kunci: M-Z-N; teknik pengujaan impulsif; ujian tanpa musnah; pencirian bahan; isyarat getaran

\section{INTRODUCTION}

Knowledge on the properties and behaviour of materials is fundamental for engineers, as the compatibility of the materials with certain applications must be met before used. The study of material characterisation is important in knowing more about the behaviour of materials so that the utilisation of the materials could be varied and used to the utmost potential (Tan et al. 2011). Material characterisation is widely applied in the area of failure analysis to prevent engineering breakdown especially undesirable catastrophic and cascading ones. In the area where safety, reliability and quality control are highly considered, the continuous development of analysis technique and measurement technology for materials characterisation becomes inevitable.

Characterisation of material refers to a description of the composition and structure a certain kind of material that involves the study and usage of the material properties, along with sufficient of material reproduction of the material (Groves \& Wachtman 1985). Among the factors, 
the success of this process is the availability of material characterisation in various techniques for carrying out the scope and knowledge so that it can be applied and implement efficiently in the field of materials engineering.

Materials properties and their behaviour are generally determined using 2 testing methods, which are destructive and non-destructive test (NDT). For destructive test, the behaviour of the sample is tested under different loads until material is ultimately fail or broken. Meanwhile, NDT concept is used to define or accessed the properties or behaviour of the material without failing, broken or damaging the sample. Therefore, non-destructive method is preferred by the researchers as the same sample can be re-used time after time for further test without fail. Besides, the test can be done with low cost, precise and no constraint in size and geometry. (Alfano \& Pagnotta 2007)

Impulsive excitation technique (IET) is one of the NDT methods that used to measure the natural frequency, based on the vibration analysis of specimens by gently tapping using small hammer or any automated tapping device. By using this technique, researchers can measure the elastic properties of materials such as elastic modulus, shear modulus and Poisson's ratio. (dos Santos et al. 2013; Węglewski et al. 2013)

Generally, material properties can be measured using conventional methods on certain industrial machines. For example, tensile or yield strength can be obtained by universal testing machine, while transient plane source methods can be used to identified thermal conductivity of certain materials. (Dupleix et al. 2013; Ramesh et al. 2013) However, these conventional methods require expensive equipment and experimental set-up. The limitation of shape and dimensions of specimens for each types of machine for experiment as well as the complex working principle of the experimental methods also contribute to increase of cost and time. (Tognana et al. 2010)

The paperwork describes an alternative method for characterising tensile strength and thermal conductivity of materials based on impulsive excitation technique. It is carried out on polymer materials to obtain the vibration data signal and alternative statistical analysis method, Mesokurtosis Zonal Nonparametric (M-Z-N) have been applied for further investigation. The past studies had also using the same technique, where they used M-Z-N analysis method combining with Integrated Kurtosis-Based Algorithm for Z-filter (I-kaz $\left.{ }^{\mathrm{TM}}\right)$ technique to characterise the fatigue strength and young modulus properties of metallic materials, by correlating the M-Z-N and I-kazTM coefficients with vibration and acoustic signal. (Nuawi et al. 2013; Nuawi et al. 2014)

\section{METHODOLOGY}

EXPERIMENTAL SETUP

The set-up of experiment is schematically shown in Figure 1. It consists of $\mathrm{PCB}$ model $086 \mathrm{C} 03$ impact hammer, Endevco 751-100 accelerometer sensor, National
Instruments NI 9234 data acquisition device, computer with LabVIEW software, support system and polymer specimens. The specimens being used are Acrylics (AC), Poly vinyl chloride (PVC), Polyethylene (PE), Cast Nylon (MC), and Polyoxymethylene (POM), with $21 \mathrm{~cm}$ length and $3 \mathrm{~cm}$ diameter of size. ASTM E1876 standard is used as a guide and reference for this experiment as it is a standard test method conducted to find dynamic young modulus, shear modulus, and poisson's ratio by impulse excitation of vibration. Table 1 below shows the theoretical value of tensile strength and thermal conductivity for all specimens using Cambridge Engineering Selector (CES Edupack) software. This software provides a comprehensive database of materials and process information, and can be used as a powerful materials software tools.

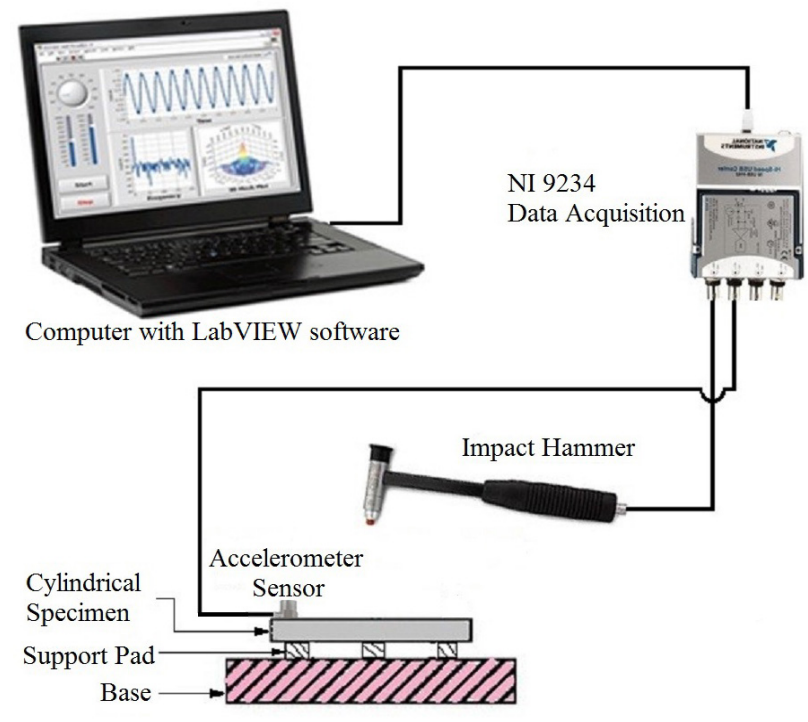

FIGURE 1. Schematic illustration of experiment preparatory

TABLE 1 . The values of tensile strength and thermal conductivity from CES Edupack

\begin{tabular}{ccc}
\hline Material & $\begin{array}{c}\text { Tensile Strength } \\
(\mathrm{MPa})\end{array}$ & $\begin{array}{c}\text { Thermal Conductivity } \\
(\mathrm{W} / \mathrm{m} . \mathrm{K})\end{array}$ \\
\hline Acrylic (AC) & 48.3 & 0.251 \\
Polyvinylchloride & 40.7 & 0.293 \\
(PVC) & & \\
Polyethylene (PE) & 20.7 & 0.435 \\
Cast nylon (MC) & 90.0 & 0.253 \\
$\begin{array}{c}\text { Polyoxymethylene } \\
\text { (POM) }\end{array}$ & 67.0 & 0.350 \\
\hline
\end{tabular}

The experiment is conducted in UKM semi-anechoic chamber to ensure clean signal recording without noise and unwanted reverberation. Support pad is fixed on the rectangular plate base where it is firmly placed on the floor. Specimen is fixed on the support pad and the accelerometer sensor is placed on the outer edge of the specimen. Impulse excitation test is done by triggering each of the specimen with an impact hammer ranging from 200 to $950 \mathrm{~N}$ of impact force. 


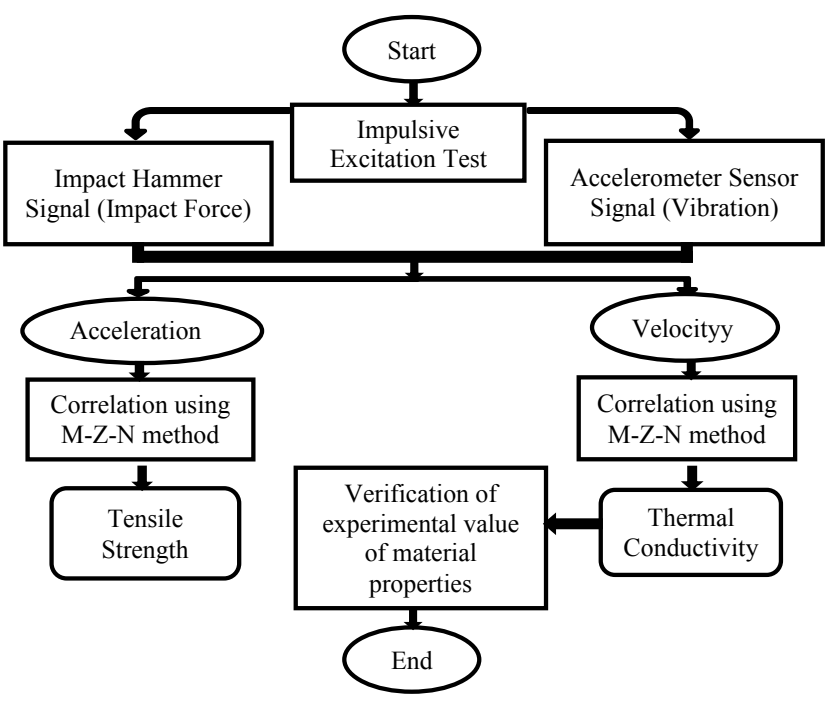

FIGURE 2. Flowchart of the research

Figure 2 shows the flowchart of the whole research. The experiment is conducted based on the impulse excitation technique where the dynamic response of specimens due to the vibration when subjected to impact force is measured using accelerometer sensor, and the signal are recorded in the form of an electrical signal using LabVIEW software in computer. This technique was recognised by researchers as previous studies were done by recording or capturing signal in the form of generated electrical signal (Alfano \& Pagnotta 2007; Guo \& Tse 2013). Two main parameters are obtained when the signal is captured which are the acceleration and velocity data. These parameter is analysed using alternative statistical of M-Z-N methods. The determination of the material properties is done by correlating the M-Z-N coefficient values with the impact force. Tensile strength and thermal conductivity which are obtained from the correlation model equation are verified by comparing them with the theory values from CES EduPack software, and the percentage error are investigated.

The signal data resulted from the experiment are analysed using Mesokurtosis Zonal Non-parametric (M-Z-N) statistical analysis method. As stated by Nuawi et al. (2013), M-Z-N method was developed based on data scattering concept with respect to the root mean square $(r m s)$ representing the content energy of signal. The $r m s$ can be calculated using Equation 1 below:

$$
r m s=\sqrt{\frac{1}{n} \sum_{i=1}^{n} x_{i}^{2}}
$$

where $x_{i}$ is the value of the signal data and $n$ is the number of data in a sample sequence. The M-Z-N coefficient can then be computed using Equation 2 below with the included r.m.s values.

$$
M-Z-N=\frac{1}{M} \sum_{j=1}^{M}\left[\frac{1}{N} \sum_{i=1}^{N}\left(x_{i}-r m s\right)^{2}\right]
$$

Where $M$ is number of segment, $N$ is the number of data, is the discrete data value of $i$-th sample and $r m s$ is the root mean square for a segment. M-Z-N method is different if compared with a previous alternative statistical analysis, which was Integrated Kurtosis-Based Algorithm for Z-notch Filter (I-kaz ${ }^{\mathrm{TM}}$ ). It was also pioneered by Nuawi et al. (2008) and based on the concept of dispersion data from the centroid of the scattering data. The I- $\mathrm{kaz}^{\mathrm{TM}}$ is mainly used for random signal analysis while M-Z-N is used for transient signal.

\section{RESULT AND DISCUSSION}

In this study, there are 2 types of parameter that are measured, in which they are impact forces and vibration signal. These signal are generated during the process of impact excitation between the impact hammer and the specimen. The impact force and vibration signal of each experiment are measured in time domain.

IMPACT AND VIBRATION SIGNAL

Figure 3 shows the example of impact force signal of 210 $\mathrm{N}$ and $900 \mathrm{~N}$ derived from POM specimens.

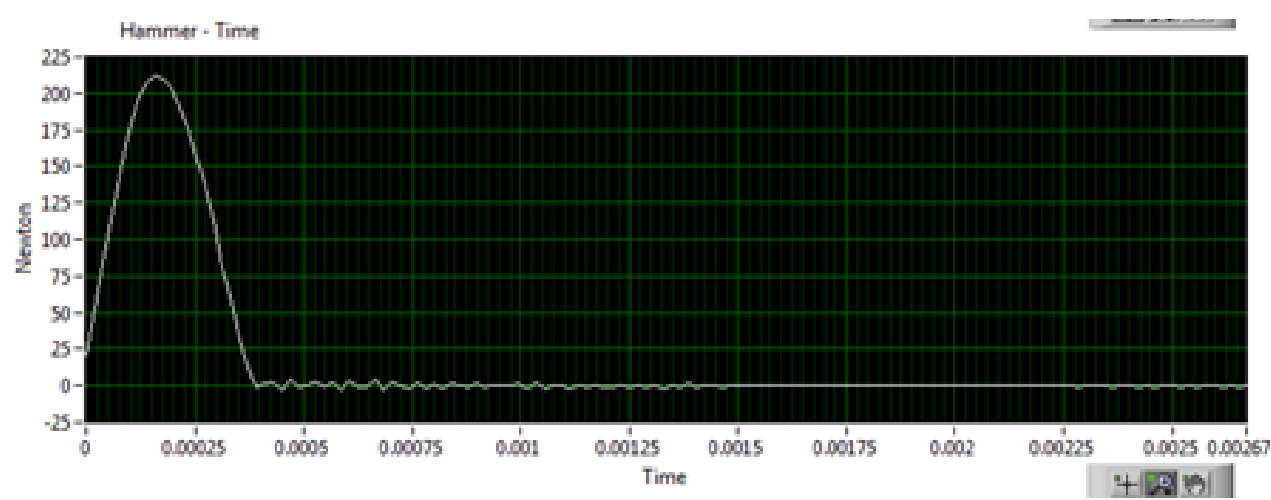

(a) 


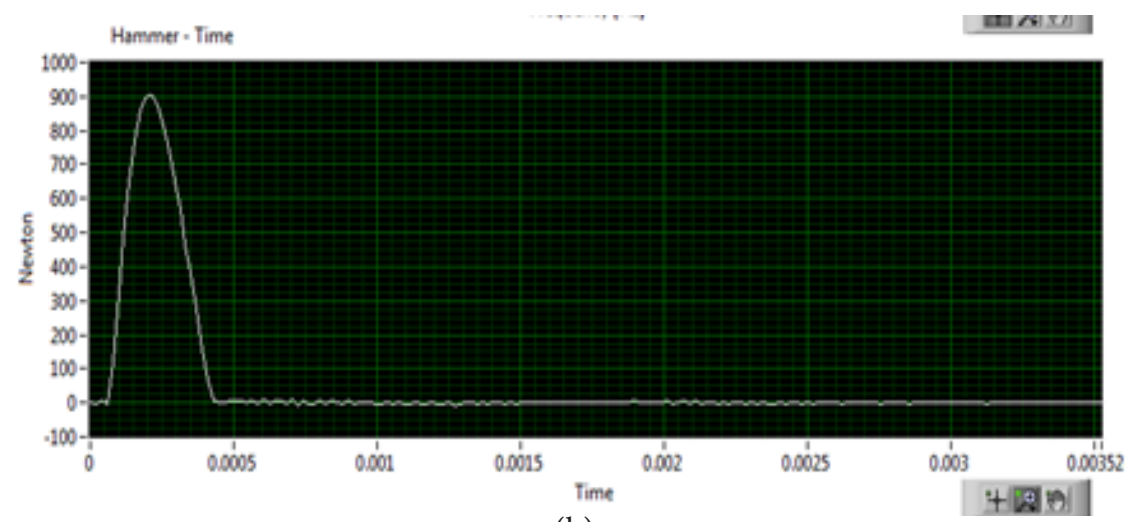

(b)

FIGURE 3. Impact force signal of POM specimens

(a) $210 \mathrm{~N}$ (b) $900 \mathrm{~N}$

Meanwhile, the captured vibration signal shows 2 types of measurement data, which are acceleration and velocity.
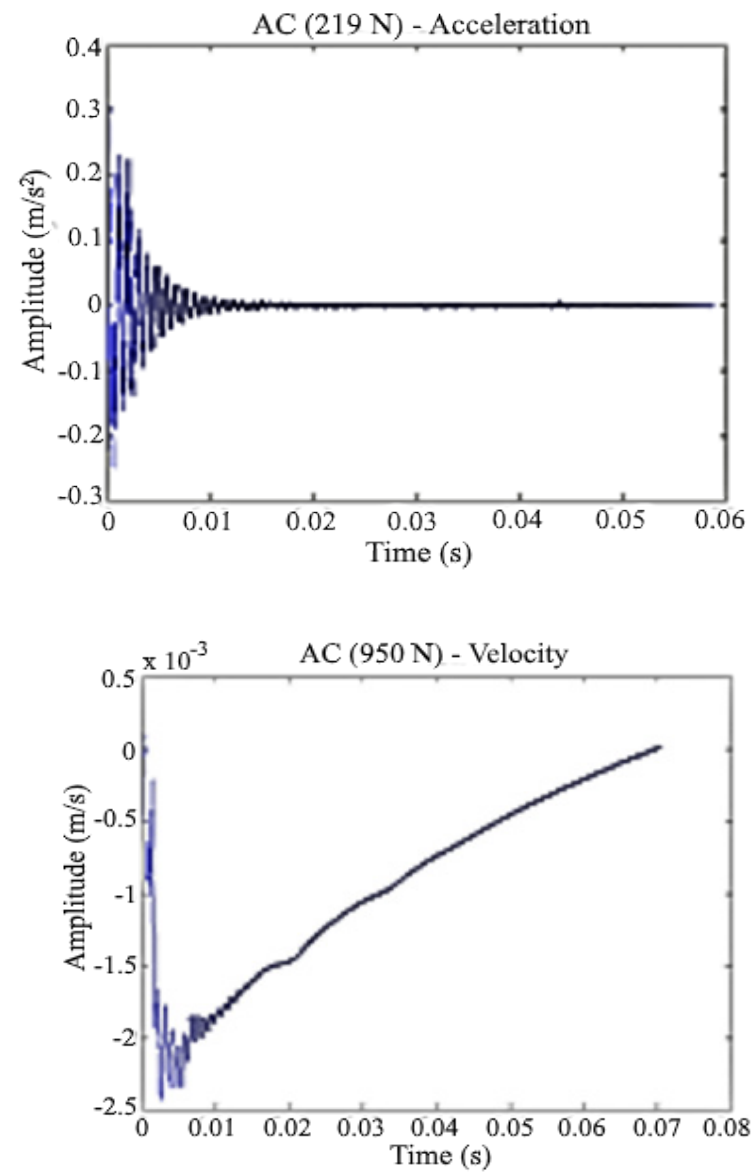

(b)

(a)

Figure 4 shows the vibration signal in time domain for $\mathrm{AC}$ specimen with specific impact force.
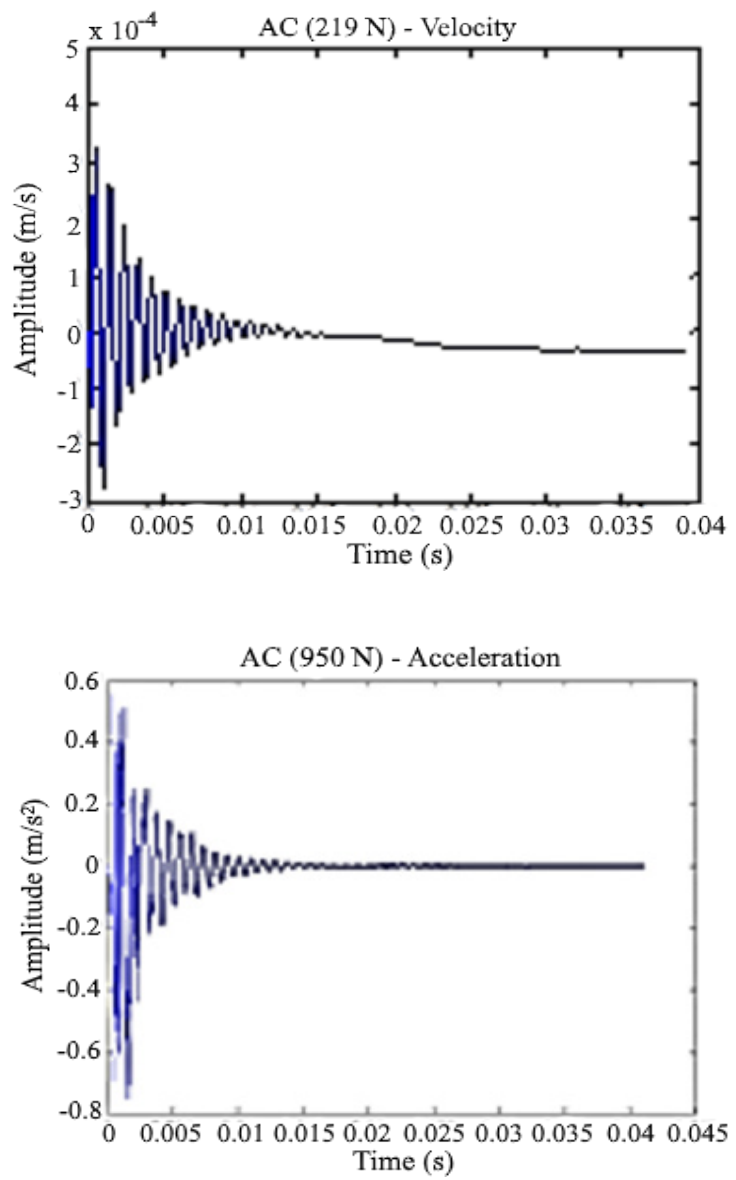

FIGURE 4. The vibration signals for AC specimen (a) Acceleration and velocity for $219 \mathrm{~N}$

(b) Acceleration and velocity for $950 \mathrm{~N}$

Phenomena occurred as seen in Figure 4 is a response that happen when the impact force is applied to the material dynamically. The amplitude of the signal will start to increase rapidly to maximum level when the impact force is applied and then start to decline transiently until they reach zero.
IMPLEMENTATION OF M-Z-N ANALYSIS METHOD

In order to characterise the material properties of specimen involved, vibration signal involving velocity and acceleration data are analysed using M-Z-N method. Table 2 shows the M-Z-N coefficients obtained from acceleration and velocity data on all specimens used, ranging from 219 to $950 \mathrm{~N}$ of impact force. 
TABLE 2. The values of M-Z-N coefficient of acceleration and velocity signal for all specimens

\begin{tabular}{|c|c|c|}
\hline \multicolumn{3}{|c|}{ Acrylic (AC) } \\
\hline \multirow[t]{3}{*}{$\mathrm{F}(\mathrm{N})$} & Acceleration & Velocity \\
\hline & (M-Z-N & (M-Z-N \\
\hline & Coefficient) & Coefficient) $* 10^{-8}$ \\
\hline 0 & 0 & 0 \\
\hline 219 & 0.0017 & 0.5193 \\
\hline 313 & 0.0037 & 4.2796 \\
\hline 476.5 & 0.0038 & 9.897 \\
\hline 502.5 & 0.0054 & 10.302 \\
\hline 630 & 0.0129 & 10.171 \\
\hline 712 & 0.0159 & 16.046 \\
\hline 810 & 0.0245 & 20.354 \\
\hline 950 & 0.033 & 31.503 \\
\hline \multicolumn{3}{|c|}{ Polyethylene (PE) } \\
\hline \multirow[t]{3}{*}{$\mathrm{F}(\mathrm{N})$} & Acceleration & Velocity \\
\hline & (M-Z-N & $(\mathrm{M}-\mathrm{Z}-\mathrm{N}$ \\
\hline & Coefficient) & Coefficient) $* 10^{-8}$ \\
\hline 0 & 0 & 0 \\
\hline 219 & 0.00051031 & 0.26901 \\
\hline 313 & 0.00059478 & 0.59613 \\
\hline 476.5 & 0.0015 & 22.765 \\
\hline 502.5 & 0.0087 & 44.536 \\
\hline 630 & 0.0182 & 50.442 \\
\hline 712 & 0.0242 & 65.113 \\
\hline 810 & 0.0421 & 75.563 \\
\hline 950 & 0.0472 & 82.962 \\
\hline
\end{tabular}

\begin{tabular}{ccc}
\hline \multicolumn{3}{c}{ Cast Nylon (MC) } \\
\hline F $(\mathrm{N})$ & $\begin{array}{c}\text { Acceleration } \\
(\mathrm{M}-Z-\mathrm{N} \\
\text { Coefficient) }\end{array}$ & $\begin{array}{c}\text { Velocity } \\
(\mathrm{M}-\mathrm{Z}-\mathrm{N} \\
\text { Coefficient) } * 10^{-8}\end{array}$ \\
\hline 0 & 0 & 0 \\
219 & 0.002 & 0.27362 \\
313 & 0.0052 & 2.7897 \\
476.5 & 0.0043 & 3.1625 \\
502.5 & 0.0072 & 7.7063 \\
630 & 0.0145 & 12.114 \\
712 & 0.0164 & 13.681 \\
810 & 0.0214 & 17.314 \\
950 & 0.024 & 18.697 \\
\hline
\end{tabular}

\begin{tabular}{ccc}
\hline \multicolumn{3}{c}{ Polyvinylchloride (PVC) } \\
\hline F (N) & $\begin{array}{c}\text { Acceleration } \\
\text { (M-Z-N } \\
\text { Coefficient) }\end{array}$ & $\begin{array}{c}\text { Velocity } \\
\text { (M-Z-N } \\
\text { Coefficient) } * 10^{-8}\end{array}$ \\
\hline 0 & 0 & 0 \\
219 & 0.0014 & 1.8343 \\
313 & 0.0017 & 6.2023 \\
476.5 & 0.0099 & 11.08 \\
502.5 & 0.0108 & 20.815 \\
630 & 0.0245 & 28.854 \\
712 & 0.0248 & 39.864 \\
810 & 0.0306 & 43.0616 \\
950 & 0.0499 & 47.0172 \\
\hline
\end{tabular}

\begin{tabular}{ccc}
\hline \multicolumn{3}{c}{ Polyoxymethylene (POM) } \\
\hline F $(\mathrm{N})$ & $\begin{array}{c}\text { Acceleration } \\
(\mathrm{M}-\mathrm{Z}-\mathrm{N}\end{array}$ & $\begin{array}{c}\text { Velocity } \\
(\mathrm{M}-\mathrm{Z}-\mathrm{N}\end{array}$ \\
& Coefficient) & Coefficient $* 10^{-8}$ \\
\hline 0 & 0 & 0 \\
219 & 0.0031 & 0.6225 \\
313 & 0.0035 & 2.995 \\
476.5 & 0.0114 & 6.902 \\
502.5 & 0.0119 & 17.238 \\
630 & 0.0146 & 19.835 \\
712 & 0.0198 & 26.753 \\
810 & 0.021 & 30.18 \\
950 & 0.0302 & 47.364 \\
\hline
\end{tabular}

Referring to the result obtained, a significant feature is identified where M-Z-N coefficients of both acceleration and velocity are increased when a higher impact force is applied to the specimen.

In order to characterise the material properties of materials, the changing of these M-Z-N coefficients with respect to the impact force applied on the specimens has to be examined by plotting the data from Table 2 for five different polymers. Figure 5 and 6 shows the plotted data of M-Z-N coefficient against impact force for both acceleration and velocity.

\section{CORRELATION BETWEEN ACCELERATION SIGNAL AND TENSILE STRENGTH}

Based on Figure 5, a quadratic polynomial curve fitting is used to calibrate the M-Z-N coefficients. Quadratic equations for the curves are well fit in the form of as it shows a good value of correlation of determination, $\mathrm{R}^{2}$ ranging from 0.949 to 0.983 . Table 3 shows the value of $\mathrm{R}^{2}$ and quadratic equation obtained from Figure 5 for acceleration data. 


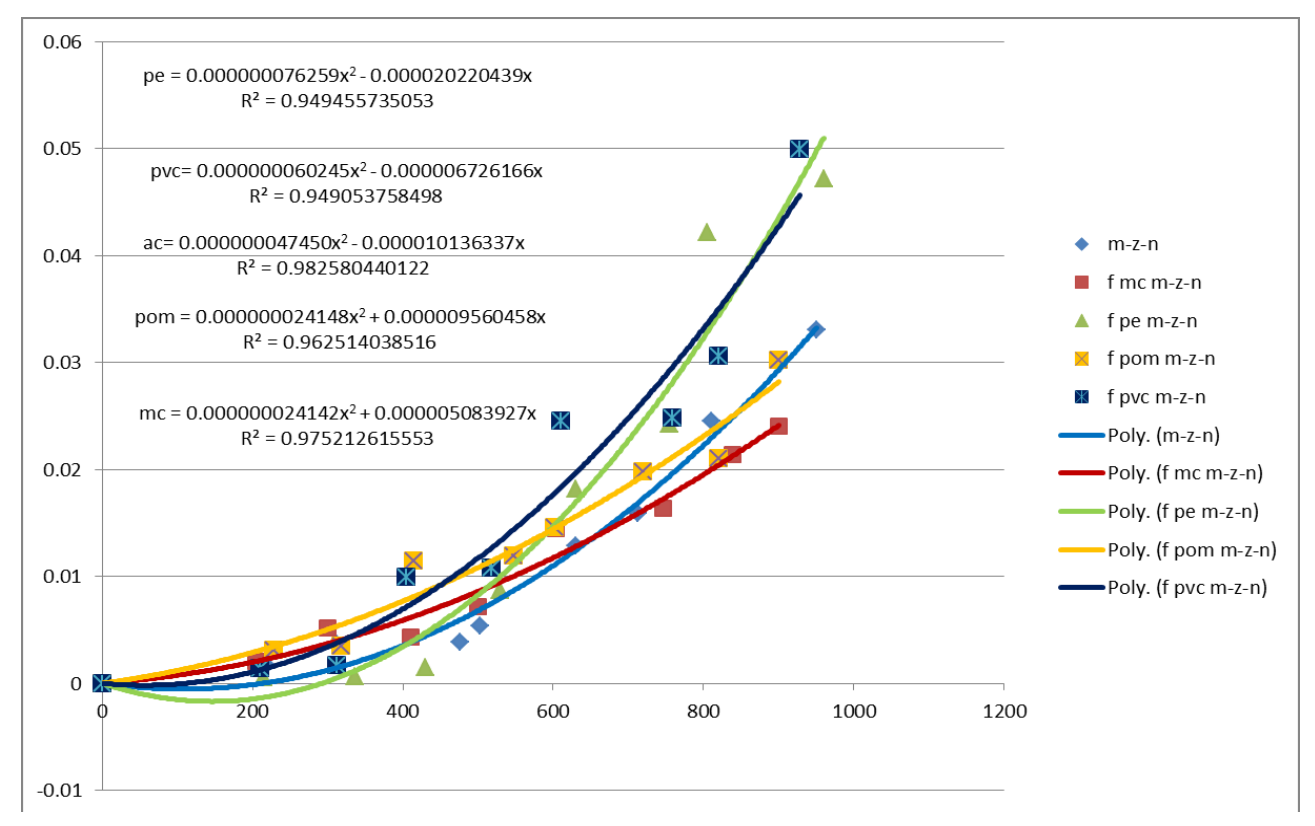

FIGURE 5. M-Z-N coefficient for acceleration signal versus impact force for all types of polymer

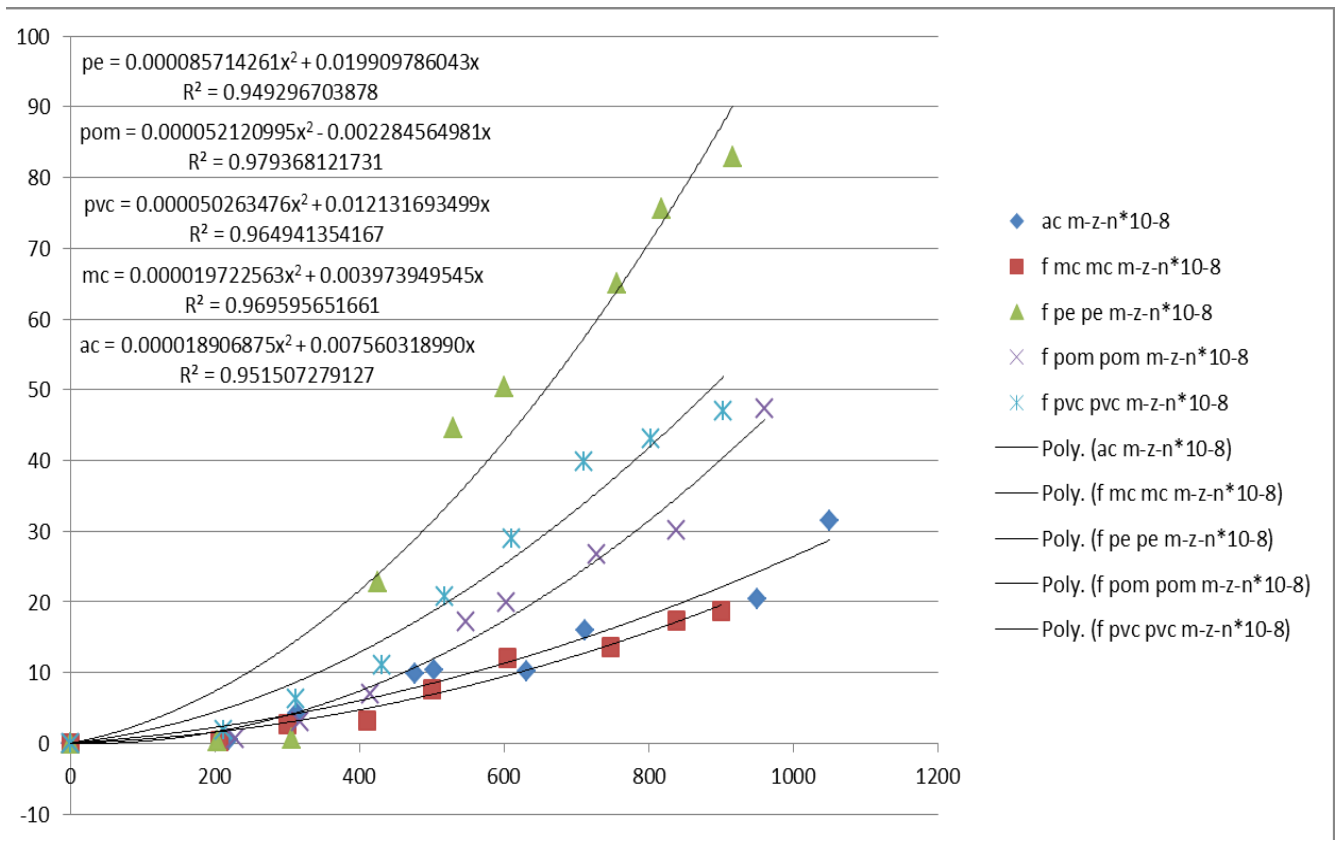

FIGURE 6. M-Z-N coefficient for velocity signal versus impact force for all types of polymer

TABLE 3. Quadratic equation and $\mathrm{R}^{2}$ of polymers for acceleration data

\begin{tabular}{lcc}
\hline \multicolumn{1}{c}{ Material } & \multicolumn{1}{c}{$\begin{array}{c}\text { Quadratic } \\
\text { Equation }\end{array}$} & $\begin{array}{c}\text { correlation of } \\
\text { determination, } \mathrm{R}^{2}\end{array}$ \\
\hline Polyethylene (PE) & $\mathrm{y}=0.000000076259 \mathrm{x}^{2}-0.000020220439 \mathrm{x}$ & 0.949 \\
Polyvinylchloride (PVC) & $\mathrm{y}=0.000000060245 \mathrm{x}^{2}-0.000006726166 \mathrm{x}$ & 0.949 \\
Acrylic (AC) & $\mathrm{y}=0.000000047450 \mathrm{x}^{2}-0.000010136337 \mathrm{x}$ & 0.982 \\
Polyoxymethylene (POM) & $\mathrm{y}=0.000000024148 \mathrm{x}^{2}+0.000009560458 \mathrm{x}$ & 0.962 \\
Cast nylon (MC) & $\mathrm{y}=0.000000024142 \mathrm{x}^{2}+0.000005083927 \mathrm{x}$ & 0.975 \\
\hline
\end{tabular}


The difference between these quadratic equations can be characterised clearly from its quadratic coefficient. The quadratic coefficient refers to the degree of the curvature and it is used to find the relationship between the vibration signal and the mechanical properties of the polymer. The quadratic coefficients of M-Z-N are arranged in ascending order where Table 4 shows the coefficient from acceleration signal and tensile strength for all materials using CES Edupack software (theoretical values) as shown in Table 1 before.

TABLE 4. M-Z-N quadratic coefficients and theoretical tensile strength of polymers

\begin{tabular}{lcc}
\hline Material & $\begin{array}{c}\text { Quadratic } \\
\text { Coefficients of M-Z-N }\end{array}$ & $\begin{array}{c}\text { Tensile Strength from } \\
\text { CES (MPa) }\end{array}$ \\
\hline Cast nylon (MC) & $2.4142 \mathrm{E}-08$ & 90.0 \\
Polyoxymethylene (POM) & $2.4148 \mathrm{E}-08$ & 67.0 \\
Acrylic (AC) & $4.745 \mathrm{E}-08$ & 48.3 \\
Polyvinylchloride (PVC) & $6.0245 \mathrm{E}-08$ & 40.7 \\
Polyethylene (PE) & $7.6259 \mathrm{E}-08$ & 20.7 \\
\hline
\end{tabular}

The trend can be observed clearly that a lower quadratic coefficient is obtained when a tensile strength of material increases. Thus, the expression for correlation between M-Z-N quadratic coefficient and tensile strength can be done. The data except for polyoxymethylene (POM) from Table 4 is plotted as shown in Figure 7. POM material is excluded from correlation as it will be used for verification purposes later on.

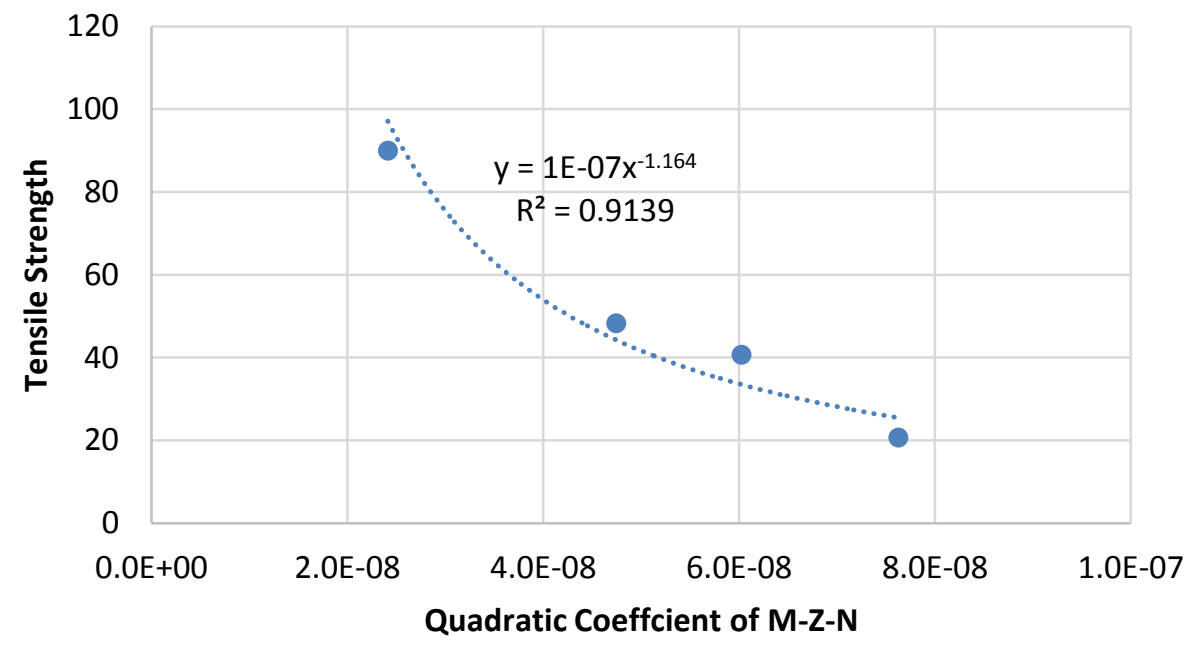

FIGURE 7. Tensile strength versus M-Z-N quadratic coefficient

TABLE 5. Quadratic equation and $\mathrm{R}^{2}$ of polymers

\begin{tabular}{lcc}
\hline Material & \multicolumn{1}{c}{$\begin{array}{c}\text { Quadratic } \\
\text { equation }\end{array}$} & $\begin{array}{c}\text { Coefficients of } \\
\text { determination }\left(\mathrm{R}^{2}\right)\end{array}$ \\
\hline Polyethylene (PE) & $\mathrm{y}=0.000085714261 \mathrm{x}^{2}+0.019909786043 \mathrm{x}$ & 0.949 \\
Polyoxymethylene (POM) & $\mathrm{y}=0.000052120995 \mathrm{x}^{2}-0.002284564981 \mathrm{x}$ & 0.979 \\
Polyvinylchloride (PVC) & $\mathrm{y}=0.000050263476 \mathrm{x}^{2}+0.012131693499 \mathrm{x}$ & 0.964 \\
Cast nylon (MC) & $\mathrm{y}=0.000019722563 \mathrm{x}^{2}+0.003973949545 \mathrm{x}$ & 0.969 \\
Acrylic (AC) & $\mathrm{y}=0.000018906875 \mathrm{x}^{2}+0.007560318990 \mathrm{x}$ & 0.951 \\
\hline
\end{tabular}

The mathematical model equation in identifying the tensile strength is in the form of power function as shown in Equation 3.

$$
\mathrm{y}=-1 \mathrm{E}-07 x^{-1.164}
$$

It can be rewritten into Equation 4 below.

$T S=(-1 \mathrm{E}-07)(\mathrm{Quadratic} \text { Coefficients of } \mathrm{M}-\mathrm{Z}-\mathrm{N})^{-1.164}$

where $T S$ is the tensile strength of material.
CORRELATION BETWEEN VELOCITY SIGNAL AND THERMAL CONDUCTIVITY

As seen on Figure 6, quadratic polynomial equation in the form of is chosen for velocity signal as it shows a good value of $\mathrm{R}^{2}$, ranging from 0.949 to 0.979 . Table 5 shows the value of $\mathrm{R}^{2}$ and the quadratic equations obtained from Figure 6. 
TABLE 6. M-Z-N quadratic coefficients and thermal conductivity of polymers

\begin{tabular}{lcc}
\hline \multicolumn{1}{c}{ Material } & $\begin{array}{c}\text { Quadratic Coefficients of } \\
\text { M-Z-N }\end{array}$ & $\begin{array}{c}\text { Thermal Conductivity from CES } \\
\text { (W/m.K) }\end{array}$ \\
\hline Polyethylene (PE) & $8.57143 \mathrm{E}-05$ & 0.435 \\
Polyoxymethylene (POM) & $5.2121 \mathrm{E}-05$ & 0.350 \\
Polyvinylchloride (PVC) & $5.02635 \mathrm{E}-05$ & 0.293 \\
Cast nylon (MC) & $1.97226 \mathrm{E}-05$ & 0.253 \\
Acrylic (AC) & $1.89069 \mathrm{E}-05$ & 0.251 \\
\hline
\end{tabular}

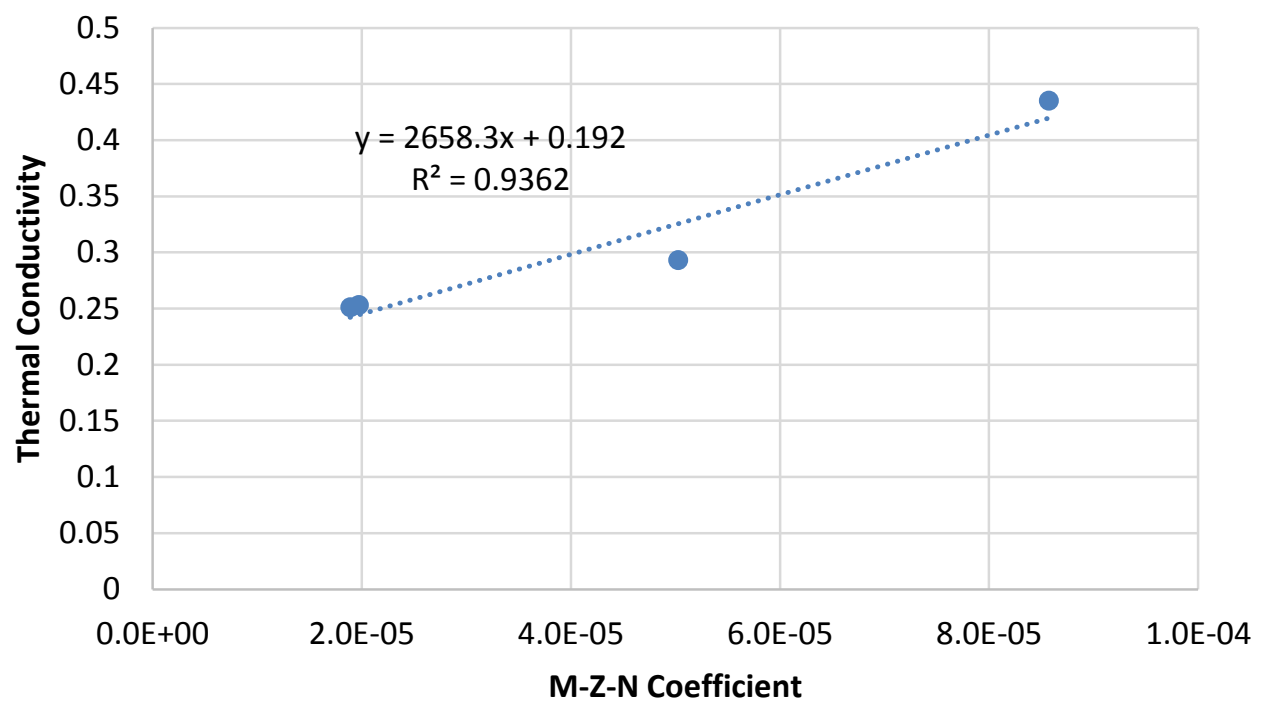

FIGURE 8. Thermal Conductivity versus M-Z-N quadratic coefficient of vibration

TABLE 7. Experimental and theoretical values of tensile strength and thermal conductivity of POM material

\begin{tabular}{lccc}
\hline & Experimental & Theory & Error \\
\hline Tensile Strength & $73.528 \mathrm{MPa}$ & $67.0 \mathrm{MPa}$ & $9.74 \%$ \\
Thermal Conductivity & $0.330553 \mathrm{~W} / \mathrm{m} . \mathrm{K}$ & $0.35 \mathrm{~W} / \mathrm{m} . \mathrm{K}$ & $5.55 \%$ \\
\hline
\end{tabular}

The quadratic coefficients are extracted from the equation and presented in Table 6 along with thermal conductivity from CES Edupack that are arranged in descending order, as shown in Table 1 before.

The relationship from the table can be seen clearly, where a higher thermal conductivity will produce an increase value of M-Z-N quadratic coefficient. Thus, the expression for correlation can be done and the graph of the Thermal Conductivity against M-Z-N quadratic coefficient has been plotted as shown in Figure 8. POM is still being excluded from correlation as it will be used for verification process.
The mathematical expression of model equation for thermal conductivity determination is well fit in the form of linear function as shown in Equation 5.

$$
y=2658.3 x+0.192
$$

It can be rewritten into Equation 6 below.

$k=2658.3 \times($ quadratic coefficient of $\mathrm{M}-\mathrm{Z}-\mathrm{N})+0.192$

where $k$ is the thermal conductivity of material. 
VERIFICATION OF MATHEMATICAL MODEL EQUATIONS

In order to verify the accuracy and validity of both of the model equations, the value of M-Z-N quadratic coefficient of
POM material which was excluded previously in correlation from table 4 and table 6 are substituted in Equation 4 and Equation 6 to obtain the experimental tensile strength and thermal conductivity as follow:

$$
\begin{aligned}
& T S=(-1 E-07)(2.4148 E-08)^{-1.164}=73.528 \mathrm{MPa} \\
& k=2658.3 \times(5.2121 E-05)+0.192=0.330553 \mathrm{~W} / \mathrm{m} . \mathrm{K}
\end{aligned}
$$

These values are compared with the theoretical value obtained from CES Edupack as shown in Table 1 which is 67

$$
\text { Error for Tensile Strength }=|73.528-67| / 67 \times 100 \%=9.74 \%
$$$$
\text { Error for Thermal Conductivity }=|0.330553-0.35| / 0.35 \times 100 \%=5.55 \%
$$

Theoretical and experimental value along with the errors for POM material are presented in Table 6.

The errors as shown in the table are below $10 \%$, which means that the above model equations are verified and valid to be used for determining the tensile strength and thermal conductivity.

\section{CONCLUSION}

In this study, material characterisation of polymer based on the impact excitation technique (IET) using M-Z-N alternative statistical analysis have been presented. The scope of material characterisation is further expanded with the implementation of Mesokurtosis Zonal Nonparametric $(M-Z-N)$. The vibration and impact signal that are captured during experiment are analysed using M-Z-N analysis method. Correlation between the M-Z-N coefficient with the experimental data have been done to observe the relationship between them. As a result, the experimental value of tensile strength and thermal conductivity have been characterised by constructing the mathematical model representation. The obtained mathematical model equations are verified and found that it is valid to be used as the calculated error of these properties is only $5.55-9.74$ $\%$. This study can contribute to a simple characterisation process of IET based on analytical methods as it does not require the use of complex and expensive machinery to work.

\section{ACKNOWLEDGEMENTS}

The authors wish to express their gratitude to Department of Mechanical and Materials Engineering, Universiti Kebangsaan Malaysia and the Ministry of Higher Education for providing financial support under ERGS/1/2013/TK01/ $\mathrm{UKM} / 02 / 2$ grant.
$\mathrm{MPa}$ and $0.35 \mathrm{~W} / \mathrm{m} . \mathrm{K}$. The percentage error of the difference between the two values are computed as shown below:

\section{REFERENCES}

Alfano, M. \& L. Pagnotta 2007. A non-destructive technique for the elastic characterization of thin isotropic plates. NDT \& E International 40(2): 112-120.

dos Santos, J. P. L., P. M. Amaral, A. C. Diogo \& L. G. Rosa 2013. Comparison of Young's Moduli of Engineered Stones Using Different Test Methods. Key Engineering Materials 548: 220-230.

Dupleix, A., A. Kusiak, M. Hughes \& F. Rossi 2013. Measuring the thermal properties of green wood by the transient plane source (TPS) technique. Holzforschung 67(4): 437-445.

Groves, D.\& J. Wachtman 1985. Materials characterizationvital and often successful, yet still a critical problem. Materials and Society 9(1): 45-58.

Guo, W. \& P. W. Tse 2013. A novel signal compression method based on optimal ensemble empirical mode decomposition for bearing vibration signals. Journal of sound and vibration 332(2): 423-441.

Nuawi, M., A. Bahari, S. Abdullah, A. Ihsan \& M. Ali 2013. Mesokurtosis zonal nonparametric signal analysis for dynamic characterisation of metallic material. Jurnal Kejuruteraan (Journal of Engineering) 24: 21-27.

Nuawi, M. Z., A. R. Bahari, S. Abdullah \& A. K. Ariffin 2014. Comparison of Young's modulus property determination of metallic materials under two statistical analysis methods. Advanced Materials Research 894: 186-191.

Nuawi, M. Z., A. R. Bahari, S. Abdullah, A. K. Ariffin \& Z. M. Nopiah 2013. Time domain analysis method of the impulse vibro-acoustic signal for fatigue strength characterisation of metallic material. Procedia Engineering 66: 539-548. 
Nuawi, M. Z., M. J. M. Nor, N. Jamaludin, S. Abdullah, F. Lamin \& C. K. E. Nizwan 2008. Development of integrated kurtosis-based algorithm for z-filter technique. Journal of Applied Sciences 8(8): 15411547.

Ramesh, M., K. Palanikumar \& K. H. Reddy 2013. Mechanical property evaluation of sisal-jute-glass fiber reinforced polyester composites. Composites Part B: Engineering 48: 1-9.

Standard, A. 1876. 09, "Standard test method for dynamic Young's modulus, shear modulus, and Poisson's ratio by impulse excitation of vibration," ASTM International, West Conshohocken, PA, 2003. DOI: 10.1520/E1876-09.

Tan, M. M. A., F. Mat, I. A. Rahim, N. T. Lile \& S. Yaacob 2011. Classification of materials by modal analysis and neural network. Information Technology and Multimedia (ICIM), 2011 International Conference on. pp. 1-5.

Tognana, S., W. Salgueiro, A. Somoza \& A. Marzocca. 2010. Measurement of the Young's modulus in particulate epoxy composites using the impulse excitation technique. Materials Science and Engineering: $A$ 527(18): 4619-4623.
Węglewski, W., K. Bochenek, M. Basista, T. Schubert, U. Jehring, J. Litniewski \& S. Mackiewicz. 2013. Comparative assessment of Young's modulus measurements of metal-ceramic composites using mechanical and non-destructive tests and microCT based computational modeling. Computational Materials Science 77: 19-30.

Muhamad Arif Fadli Ahmad, Mohd Zaki Nuawi*, Nadia F. Mohamed, Zaliha Wahid \& M. Dirhamsyah Department of Mechanical and Materials Engineering Faculty of Engineering and Built Environment Universiti Kebangsaan Malaysia,

43600 UKM Bangi, Selangor, Malaysia

*Corresponding author; email: mzn@ukm.edu.my

Received date: $15^{\text {th }}$ August 2015

Accepted date: $25^{\text {th }}$ February 2016 